\title{
Perlindungan Hukum Terhadap Saksi Mahkota dalam Proses Pemeriksaan Perkara Pidana
}

\author{
Habibi Rahman, Lilik Purwastuty, Dessy Rakhmawati \\ Fakultas Hukum, Universitas Jambi \\ Author's Email Correspondence:
}

\begin{abstract}
ABSTRAK
Penelitian ini membahas masalah Perlindungan Hukum terhadap Saksi

Mahkota dalam Proses Pemeriksaan Perkara Pidana. Selanjutnya data yang diperoleh baik melalui studi kepustakaan maupun hasil wawancara dianalisis dengan menggunakan metode analisis deskriptif. Hasil penelitian menunjukkan bahwa, pelaksanaan perlindungan terhadap saksi mahkota dinilai telah terlaksana hal ini dapat di lihat dari banyaknya bentuk perlindungan yang dapat diberikan kepada saksi khususnya saksi mahkota, baik dalam bentuk perlindungan fisik, psikis maupun hukum. Bentuk perlindungan fisik dan psikis berupa Perlindungan atas keamanan diri serta bebas dari ancaman dan tekanan pihak lain. Sedangkan bentuk perlindungan hukum berupa Saksi tidak dapat dituntut secara hukum baik pidana maupun perdata atas kesaksiannya dan Penanganan secara khusus bagi saksi yang juga pelaku tindak pidana yang sama (saksi mahkota). Hal ini menunjukkan adanya upaya realisasi dari aturan-aturan hukum tentang perlindungan hukum terhadap saksi mahkota. Untuk mewujutkan perlindungan hukum terhadap saksi mahkota yang lebih baik perlu adanya upaya peningkatan sosialisasi aturan-aturan hukum terkait perlindungan saksi kepada masyarakat dengan demikian masyarakat akan lebih memahami bahwa ada suatu mekanisme aturan hukum yang mengatur perlindungan terhadap seorang saksi mahkota.
\end{abstract}

ARTICLE HISTORY

Submission: 2020-11-21

Accepted: 2020-12-02

Publish: 2020-12-02

KEYWORDS: Crown

witness legal protection.
Kata Kunci: Perlindungan

hukum, saksi mahkota

\begin{abstract}
This research discusses the issue of Legal Protection for Crown Witnesses in the Criminal Case Investigation Process. The results showed that the implementation of protection for crown witnesses was considered to have been implemented. This can be seen from the many forms of protection that can be provided to witnesses, especially crown witnesses, in the form of physical, psychological and legal protection. Physical and psychological protection is in the form of protection for personal safety and freedom from threats and pressure from other parties. Meanwhile, the form of legal protection in the form of witnesses cannot be prosecuted legally, either criminal or civil, for their testimony and special handling for witnesses who are also perpetrators of the same crime (crown witness). This shows that there is an effort to realize the legal rules regarding legal protection for crown witnesses. In order to achieve better legal protection for crown witnesses, it is necessary to increase the socialization of legal rules related to witness protection to the public so that the public will better understand that there is a mechanism of legal rules regulating the protection of a crown witness
\end{abstract}




\section{A. PENDAHULUAN}

Salah satu alat bukti yang sah yang selalu ada dan diperlukan dalam setiap perkara adalah keterangan Saksi begitu pula dalam perkara Pidana. Betapa pentingnya Saksi dalam perkara Pidana dapat diketahui dari banyaknya perkara yang tidak terselesaikan dalam tahap penyidikan maupun yang kemudian membebaskan Terdakwa dari tuntutan jaksa penuntut umum karna kurangnya alat bukti Saksi. Pengertian umum dari saksi dicantumkan dalam pasal 1 butir 26 kitab Undang-undang Hukum acara pidana yang berbunyi:

"Saksi adalah orang yang dapat memberikan keterangan guna kepentinganpenyidikan, penuntutan dan peradilan tentang suatu perkara pidana yang ia dengar sendiri, ia lihat sendiri dan ia alami sendiri." ${ }^{1}$

Menjadi saksi merupakan kewajiban dari setiap warga Negara, dengan prinsip bahwa setiap Saksi dalam memberikan keterangan harus mempunyai kebebasan, tanpa ada paksaan dari siapa pun. Namun sekalipun saksi bebas memberikan keterangan, saksi juga dapat dituntut berdasarkan pasal 242 kitab Undang-Undang Hukum Pidana, apabila Saksi memberikan keterangan yang tidak sesuai dengan yang sebenarnya. ${ }^{2}$

Sistem Peradilan Pidana merujuk pada suatu cakupan Substansi yang lebih luas bila dibandingkan dengan Hukum Acara Pidana. Oleh karena itu dapat dikatakan bahwa Sistem Peradilan Pidana adalah Hukum Acara Pidana dalam art luas, sementara istilah Hukum Acara Pidana saja adalah sistem Peradilan Pidana dalam arti sempit. $^{3}$

Tahap pembuktian dalam Sistem Peradilan Pidana merupakan faktor penting untukmenentukan terbukti atau tidak terbuktinya Terdakwa melakukan pidana. Bagi Penuntut Umum proses pembuktian merupakan faktor yang sangat krusial dalam rangka mendukung tugasnya sebagai pihak yang memiliki beban untuk membuktikan terdakwa. Untuk mencapai suatu keadilan dalam proses pembuktian maka sudah seharusnya berpedoman pada asas-asas yang berlaku dalam Hukum Acara Pidana, seperti asas praduga tidak bersalah (presumption of innocence)dan asas persamaan dihadapan hukum (equality before the law), dan asas pemeriksaan (accusatoir). Bentuk dari asas praduga tidak bersalah (presumption of innocence) tercantum dalam Pasal 66 KUHAP yang berbunyi "Tersangka atau terdakwa tidak dibebani kewajiban pembuktian." Dengan dicantumkannya Pasal 66 KUHAP maka pada dasarnya siapa yang menyangka atau siapa yang mendakwa seseorang telah melakukan tindak pidana, maka ialah yang harus membuktikan kebenaran dari sangkaan atau dakwaannya. ${ }^{4}$ Dalam kapasitasnya sebagai Pihak yang berwenang mengadili, proses pembuktian bagi Hakim sangat penting dalam mendukung pembuktian faktor keyakinan Hakim. Hal itu disebutkan dalam Pasal 183 KUHAP yang pada intinya ialah Hakim menjatuhkan Pidana dengan sekurang-kurangnya dua alat bukti yang sah dan keyakinan Hakim

1 Hari Sasangka, Komentar Kitab Undang-undang Hukum Acara Pidana, Cet. 1, CVMandar Maju, Bandung, 2003, hal. 6.

2 C. Djisman Samosir, Segenggam tentang Hukum Acara Pidana, Cet. 3 Nuansa Indah, Bandung, 2013, hal. 130.

3 Luhut M.P. Pangaribuan, Hukum Acara Pidana \& Hakim Ad Hoc, Cet.1, Papas Sinar Sinanti, Jakarta, 2016, hal. 70.

4 P.A.F Lamintang dan Theo Lamintang, Pembahasan KUHAP Menurut Ilmu Pengetahuan Hukum Pidana dan Yurisprudensi, Cet. 3, Sinar Grafika, Jakarta, 2013, hal. 207. 
bahwa suatu tindak pidana benar-benar terjadi yang dilihat dari alat bukti yang sah tersebut.

Dalam sistem peradilan di Indonesia, kedudukan Saksi sangatlah penting sehingga dijadikan salah satu diantara lima alat bukti yang sah sebagaimana diatur dalam Pasal 184 (1) kitab Undang-undang Hukum acara pidana (KUHAP) yaitu:
a. Keterangan saksi
b. Keterangan ahli
c. Surat
d. Petunjuk
e. Keterangan Terdakwa

Penempatan keterangan saksi dalam urutan pertama dari lima alat bukti yang sah, menunjukkan tentang pentingnya alat bukti keterangan saksi dalam penyelesaian perkara pidana. Pentingnya alat bukti keteranagn saksi ini terkai dengan system pembuktian yang dianut oleh hukum acara pidana indonesia yaitu sistem negatif (Negative wettelijk). Sistem negatif (Negatif wettelijk) yaitu suatu system pembuktian didepan pengadilan agar suatu pidana dapat dijatuhkan karena yang dicari oleh hakim adalah kebenaran yang meteril, berbeda dengan hukum perdata yang dalam pembuktiannya mencari kebenaran formil. Sehingga dalam hukum pidana keterangan saksi sangat mempengaruhi putusan hakim. ${ }^{5}$ Hampir semua pembuktian perkara pidana selalu bersandar kepada pemeriksaan keterangan saksi, sekurang-kurangnya disamping pembuktian dengan alat bukti yang lain, selalu diperlukan pembuktian dengan alat bukti keterangan saksi.6 Pentingnya saksi dalam proses Peradilan Pidana, telah dimulai sejak awal proses peradilan pidana. Begitu pula dalam proses selanjutnya, keterangan Saksi sebagai alat bukti utama menjadi acuan bagi hakim dalam menentukan bersalah atau tidaknya terdakwa. Karena Saksi memiliki peranan penting dalam peradilan pidana, maka Saksi haruslah orang yang mendengar, melihat dan mengalami suatu kejadian yang diduga perbuatan tindak pidana.

Berdasarkan definisi tersebut, maka tidaklah mustahil saksi adalah juga korban/pihak yang dirugikan dari peristiwa tersebut. Saksi diharapkan dapat menjelaskan rangkaian kejadian yang berkaitan dengan sebuah peristiwa yang menjadi objek pemeriksaan di muka pengadilan. Saksi, bersama alat bukti lain akan membantu Hakim untuk menjatuhkan putusan yang adil dan objektif berdasarkan fakta-fakta hukum yang disampaikan.

Tetapi Saksi juga harus dibebaskan dari perasaan takut, khawatir akan dampak dari keterangan yang diberikannya. Seseorang mungkin saja menolak untuk bersaksi, atau, kalaupun dipaksa berbohong karena ia tidak mau mempertaruhkan nyawanya atau nyawa keluarganya gara-gara keterangannya yang memberatkan terdakwa. Di sisi lain, seseorang dapat menolak memberikan keterangan karena mengalami trauma hebat akibat peristiwa pidana, sehingga tidak memiliki kemampuan untuk menceritakan ulang peristiwa yang dialaminya itu. Tidak sedikit kasus yang tidak dapat dibawa ke muka pengadilan atau pun terhenti di tengah jalan karena persoalan

\footnotetext{
5 Munir Fuady, Teori Hukum Pembuktian: Pidana dan Perdata, Cet. 4, Pt. Citra Aditya Bakti, 2012, hal. 2.

6 M. Yahya Harahap, Pembahasan Permasalahan dan Penerapan KUHAP : Pemeriksaan Sidang Pengadilan, Banding, Kasasi, dan Peninjauan Kembali, Edisi Kedua, Cet. 13, Sinar Grafika, Jakarta, 2012, hal. 286.
} 
yang satu ini. Kasus-kasus seperti korupsi atau kejahatan narkotika yang melibatkan sebuah sindikat, atau kasus-kasus kekerasan berbasis gender menjadi contoh kasus yang seringkali tidak dapat diproses karena tidak ada saksi yang mau dan berani memberikan keterangan yang sebenarnya. Maka yang terjadi kemudian adalah bukan saja gagalnya sebuah tuntutan untuk melakukan proses peradilan yang bersih, jujur dan berwibawa untuk memenuhi rasa keadilan, tetapi juga pelanggaran hak-hak asasi individual yang terkait dalam kasus tersebut.

Dalam Sistem Peradilan di Indonesia terdapat istilah Saksi Mahkota, yang di maksud dengan Saksi mahkota adalah seorang tersangka atau terdakwa yang dijadikan saksi terhadap tersangka atau terdakwa lainnya, dengan kata lain menjadi saksi mahkota, maka dilakukan metode yang dikenal dengan nama Splitsing (Pemecahan Perkara Pidana), tidak semua perkara pidana dapat menggunakan saksi mahkota, hanya dalam perkara tindak pidana penyertaan saja yang menggunakan saksi mahkota.

Dengan demikian dapat dikatakan bahwa saksi mahkota juga merupakan tersangka dari perkara yang dilakukan. Disini saksi mahkota akan mendapat tekanan psikis saat memberikan keterangan dan pertanyaan-pertanyaan yang kemungkinan akan menjeratnya, karena terdakwa disumpah maka ia tidak dapat mengingkari atau membela diri.

Keberadaan Saksi Mahkota dalam sistem peradilan Indonesia di pandang mempunyai daya potensial dalam membuka tabir kejahatan. Terlebih lagi kejahatan yang melibatkan beberapa pelaku yang telah mengembangkan ikatan yang kuat satu sama lain dan bersifat tertutup, seperti halnya dalam tindak pidana Korupsi, Narkotika, dan lainnya. Ikatan seperti ini seringkali saling menguntungkan yang akan menyebabkan para pelaku tersebut untuk bersatu menghadapi penyidikan atau kemungkinan adanya sebuah tuntutan untuk melindungi kepentingan mereka. Sehubungan dengan sifat dasar dari kasus-kasus Organized Crime atau White Colar Crime maka kasus ini lebih sulit untuk dibuktikan dari pada kasus tindak pidana lainnya. ${ }^{7}$

Setiap penegakan hukum harus sesuai dengan persyaratan konstitusional, harus menaati hukum, serta harus menghormati the right of self incrimination. Tidak Seorangpun dapat dipaksa menjadi saksi yang memberatkan dirinya dalam suatu tindak pidana. Dilarang mencabut, menghilangkan hak hidup, keerdekaan, atau harta benda tanpa sesuai dengan ketentuan hukum acara. Seriap orang harus terjamin hak terhadap diri, kediaman, surat-surat atas pemeriksaan dan penyitaan yang tidak beralasan. Hak konfrontasi dalam bentuk pemeriksaan silang dengan orang yang menuduh atau melaporkan, hak memperoleh pemeriksaan yang cepat, hak perlindungan yang sama dan perlakuan yang sama di depan hukum, hak mendapat bantuan Penasihat Hukum, baik tersangka maupun saksi juga harus dilindungi haknya. Jika hak tersebut sudah diperoleh maka akan merasa sebagai

Manusia yang dihormati harkat dan martabatnya. ${ }^{8}$ Walaupun tidak diberikan suatu definisi otentik dalam KUHAP mengenai Saksi mahkota (kroongetuide), namun berdasarkan perspektif empirik maka Saksi mahkota didefinisikan sebagai Saksi yang berasal atau diambil dari salah seorang tersangka atau Terdakwa lainnya yang

Putusan Mahkama Konstitusi Nomor 42/PUU-VIII/2010 tanggal 3 September 2010, hal. 63.

Munir Fuady \& Sylvia Laura L. Fuady, Hak Asasi Tersangka Pidana, Cet. 1, Prenada Media Group, Jakarta,2015, hal. 1. 
bersama-sama melakukan perbuatan pidana, dan dalam hal mana kepada Saksi tersebut diberikan mahkota. Adapun mahkota yang diberikan kepada Saksi yang berstatus Terdakwa tersebut adalah dalam bentuk ditiadakan penuntutan terhadap perkaranya atau diberikannya suatu tuntutan yang sangat ringan apabila perkaranya dilimpahkan ke Pengadilan atau dimaafkan atas kesalahan yang pernah dilakukan. ${ }^{9}$

Tentang Saksi Mahkota ini juga ditemukan dalam Yurisprudensi Mahkama Agung Nomor 1174 K/Pid/1994 tanggal 3 mei 1995 Pasal. Nomor 1590 K/Pid/1995 tanggal 3 mei 1995 Jo. 1592 K/Pid/1994 tanggal 3 mei 1995 yang pada intinya menyatakan bahwa pemeriksaan terhadap saksi mahota sebaiknya tidak dilakukan karena hal itu bertentangan dengan hukum acara pidana dan juga merupakan pelanggaran terhadap kaidah Hak Asasi Manusia secara Universal. ${ }^{10}$

Satu-satunya putusan Pengadilan yang menolak saksi Mahkota sebagai alat bukti adalah Putusan Mahkamah Agung dalam kasus pembunuhan MARSINAH, yang menyatakan "saksi Mahkota bertentangan dengan hukum" (Putusan Mahkamah Agung Nomor 1174 K/Pid/1994, 381 K/Pid/1994, 1592 K/Pid 1994 dan 1706 K/Pid/1994). Untuk mengantisipasi kemungkinan adanya hakim yang menjadikan Putusan Mahkamah Agung dalam perkara pembunuhan terhadap Marsinah tersebut sebagai dasar putusannya, maka dalam menggunakan saksi mahkota, supaya sedapat mungkin diupayakan juga tambahan alat bukti lain. Adapun data laporan perkara pidana di Willayah Hukum Pengadilan Negeri Sarolangun yang menggunakan Saksi Mahkota terhitung sejak tahun 2018 hingga tahun 2019 adalah sebanyak 16 (enam belas) perkara, yaitu 9 (sembilan) perkara pada tahun 2018 dan 7 (tujuh) perkara pada tahun 2019. Berikuutnya dijelaskan pada tabel dibawah ini:

Tabel 1

Jumlah perkara Pidana yang mennggunakan Saksi Mahkota di Wilayah Hukum

\begin{tabular}{c|c|c} 
No & Tahun & Jumlah Perkara \\
\hline 1 & 2018 & 9 \\
2 & 2019 & 7 \\
\hline \multicolumn{2}{l}{ Jumlah } & 16
\end{tabular}

Pengadilan Negeri Sarolangun tahun 2018-2019

Berdasarkan uraian tabel 1 tersebut dapat penulis simpulkan bahwa jumlah perkara tindak pidana yang menggunakan keterangan saksi mahkota di wilayah hukum Pengadilan Negeri Sarolangun lumayan banyak, maka dari itu penulis tertarik untuk meneliti dan menelusuri lebih lanjut tentang Saksi Mahkota dalam perkara pidana, langkah selanjutnya penulis melakukan penelitian dalam rangka penulisan dengan judul "Perlindungan Hukum Terhadap Saksi Mahkota Dalam Proses Pemeriksaan Perkara Pidana"

9 Putusan Mahkamah Agung Nomor 2437 K/Pid.Sus/2011 tanggal 7 Februari 2012.

10 Putusan Mahkama Agung Nomor 250 K/MIL/2013 tanggal 25 maret 2014, hal.17. 


\section{B. METODE PENELITIAN}

Penelitian ini menggunakan metode pendekatan Yuridis Empiris, yaitu mempelajari peraturan Perundang-Undangan yang berlaku berkenaan dengan Saksi Mahkota dan melihat praktiknya berkenaan dengan perlindungan hukum yang di dapat oleh Saksi Mahkota dalam proses pemeriksaan perkara pidana

\section{PEMBAHASAN}

1. Pelaksanaan Perlindungan Hukum Terhadap Saksi Mahkota Dalam Proses Pemeriksaan Perkara Pidana Di Pengadilan Negeri Sarolangun

Di dalam Undang-undang Perlindungan saksi dan korban telah ditentukan bahwa perlindungan saksi dilakukan oleh lembaga tersendiri yang bersifat mandiri yang disebut Lembaga Perlindungan Saksi dan Korban (LPSK). Namun lembaga ini masih bersifat nasional yang berkedudukan di Ibu kota Negara, sehingga hal ini masih menjadi salah satu hambatan terhadap pelaksanaan perlindungan terhadap saksi dan korban pada tingkat daerah-daerah secara maksimal. Di Sarolangun perlindungan terhadap saksi masih dilakukan oleh penjabat yang berwenang dalam masing-masing tahap pemeriksaan, yaitu penyidik (Polri dan PPNS), jaksa penuntut umum, dan hakim. Dalam proses pemeriksaan perkara pidana di Pengadilan Negeri Sarolangun perlindungan terhadap saksi dilakukan oleh hakim, dalam hal ini perlindungan diberikaan melalui bagian Pelayanan Peradilan atau posko bantuan hukum Pengadilan Negeri Sarolangun.

Di dalam pemeriksaan persidangan perkara pidana hakim yang melakukan pemeriksaan persidangan namun tanpa adanya alat bukti, hakim tidak akan dapat mengetahui dan memahami apakah suatu tindak pidana telah terjadi dan apakah terdakwa telah benar-benar melakukan tindak pidana tersebut dan bertanggung jawab atas peristiwa itu, jadi adanya alat bukti mutlak diperlukan sehingga hakim dapat dengan pasti menemukan kebenaran materil. Dalam Pasal 183 Undang-undang Nomor 8 tahun 1981 dinyatakan : "hakim tidak boleh menjatuhkan pidana kepada seseorang kecuali apabila dengan sekurang-kurangnyadua alat bukti yang sah ia memperoleh keyakinan bahwa suatu tindak pidana benar-benar terjadi dan terdakwalah yang melakukannya" dalam Pasal 184 KUHAP menyatakan alat bukti yang sah ialah:
a. keterangan saksi
b. keterangan ahli
c. surat
d. petunjuk
e. keterangan terdakwa

Salah satu alat bukti yang disebutkan dalam Pasal 184 KUHAP adalah keterangan saksi yang merupakan alat bukti dalam perkara pidana yang berupa keterangan mengenai suatu peristiwa pidana yang ia dengar sendiri, ia lihat sendiri dan ia alami sendiri dengan menyebutkan alasan dari pengetahuannya tersebut. ${ }^{11}$ Dari hasil penelitian yang dilakukan penulis di Pengadilan Negeri Sarolangun berkaitan dengan pelaksanaan perlindungan terhadap Saksi Mahkota dalam proses pemeriksaaan perkara Pidana dinilai telah terlaksana, hal ini dapat di lihat dari

11 Yulia Monita dan Dheny Wahyudhi, Peranan Dokter Forensik Dalam Pembuktian Perkara Pidana, Jurnal Ilmu Hukum, Fakultas Hukum, Universitas Jambi, Vol. 6, No. 7, 2013, hal. 129, https://online-journal.unja.ac.id/index.php/jimih/article/view/2188. 
banyaknya bentuk perlindungan yang dapat diberikan kepada seorang saksi terkhusus saksi mahkota, baik dalam bentuk perlindungan fisik, psikis maupun hukum. Salah satu alat bukti yang sah dalam proses peradilan pidana adalah keterangan saksi dan/atau korban yang mendengar, melihat, atau mengalami sendiri terjadinya suatu tindak pidana dalam upaya mencari dan menemukan kejelasan tentang tindak pidana yang dilakukan oleh pelaku tindak pidana. Penegak hukum dalam mencari dan menemukan kejelasan tentang tindak pidana yang dilakukan oleh pelaku tindak pidana sering mengalami kesulitan karena tidak dapat menghadirkan saksi dan/atau korban disebabkan adanya ancaman, baik fisik maupun psikis dari pihak tertentu. Sehubungan dengan hal tersebut, perlu dilakukan perlindungan bagi saksi dan/atau korban yang sangat penting keberadaannya dalam proses peradilan pidana. Kesaksian memang dibutuhkan dalam setiap peradilan pidana, termasuk peradilan militer. Saksi yang dimintai keterangan dalam penyidikan maupun persidangan, pada dasarnya sangat membantu berjalannya rangkaian proses peradilan. Apalagi hasil yang diharapkan dari proses pengumpulan keterangan saksi untuk memastikan peradilan yang jujur (fair trial).12

Dalam penegakan perlindungan saksi khususnya perlindungan hukum bagi saksi itu sendiri saat ini telah diatur oleh Undang-undang Nomor 31 Tahun 2014 tentang Perubahan atas Undang-Undang Nomor 13 Tahun 2006 tentang Perlindungan Saksi dan Korban. Sebuah Undang-undang Perlindungan Saksi dan Korban yang berlaku efektif, yang dibentuk atas dasar upaya untuk mengatasi permasalahan seperti pelanggaran hak asasi manusia. Undang-undang perlindungan saksi dan korban yang diharapkan akan menolong Negara ini keluar dari persoalan-persoalan hukum yang berkepanjangan seperti sulitnya memberantas korupsi, kekerasan dalam rumah tangga, kekerasan terhadap perempuan dan belum lagi tentang perlindungan hukum yang hanya mampu menyentuh bagi kalangan konglomerat, pejabat, dan lain sebagainya. Sehingga diperlukan perlindungan hukum sebagai payung hukum bagi para saksi dan korban di masa mendatang. Undang-undang Perlindungan Saksi dan Korban, merupakan salah satu jawaban dari persoalan di atas.

Mengenai hal tersebut Penulis telah melakukan wawancara dengan salah satu Hakim di Pengadilan Negeri Sarolangun, yang memiliki kewenangan dalam memberikan perlindungan hukum terhadap saksi selama proses peradilan, dalam konteks ini berkaitan dengan pelaksanaan perlindungan hukum terhadap saksi mahkota dalam proses pemeriksaan perkara pidana, Sebagaimana dijelaskan oleh Muhammad Affan:

"Kalau mengenai pelaksanaan perlindungan hukum yang diberikan kepada saksi mahkota itu sama saja dengan perlindungan yang diberikan kepada saksi-saksi pada umumnya. Saksi mahkota inikan saksi sekaligus pelaku/terdakwa tindak pidana, ia (pelaku tindak pidana) dijadikan saksi karena kurangnya alat bukti yang ditemukan di TKP dan tindak pidana ini merupakan tindak pidana penyertaan. Saksi mahkota juga disumpah seperti halnya saksi-saksi pada umumnya sebelum memberikan kesaksian, tetapi pelaku yang dijadikan saksi ini sebelumnya ditanyakan apakah bersedia dijadikan saksi terhadap tindak pidana yang dia juga lakukan itu. Tentu perbedaannya dengan saksi pada umumnya

12 Asmilawati Jafar, Perlindungan Hukum Terhadap Saksi Dalam Pemeriksaan Perkara Pidana, Skripsi Sarjana Hukum, UIN Alauddin Makassar, 2014, hal. 54, http://repositori.uinalauddin.ac.id/6418/1/Asmilawati\%20Jafar.pdf. 
ialah saksi mahkota merupakan terdakwa yang berarti akan disidangkan diperadilan dan akan mempertanggung jawabkan perbuatannya. Mengenai di tahan atau tidaknya saksi mahkota itu perlu diketahui kalau saksi mahkota ini merupakan pelaku tindak pidana yang mungkin jika tidak ditahan ia bakal melarikan diri, selama ini saksi-saksi mahkota yang diajukan di persidangan pasti ditahan karena ia juga pelaku tindak pidana. Kalau perlakuan fisik, hukum dan lainnya yang diberikan kepada saksi mahkota itu sama saja dengan hak-hak yang diberikan kepada saksi, yang membedakan saksi mahkota ini tetap ditahan, dalam penjagaan agar tidak melarikan diri selama proses persidangan."13

Sehingga penulis menarik kesimpulan bahwasahnya pelaksanaan perlindungan hukum yang diberikan kepada saksi mahkota dalam perkara pidana, sama saja dengan saksi-saksi pada umumnya, baik dari segi hak- hak yang diberikan maupun kewajiban saksi itu sendiri. Kemudian yang membedakannya saksi mahkota dengan saksi biasa seperti yang dinyatakan oleh Hakim Pengadilan Negeri Sarolangun Muhammad Affan secara lugas ia menyebutkan beda saksi mahkota dengan saksi pada umunya ialah kalau saksi mahkota dilakukan penahanan karena ia juga merupakan pelaku tindak pidana tetapi kalau saksi biasa tidak dilakukan penahanan. Penulis juga melakukan wawancara dengan seorang Jaksa di Kejaksaan Negeri Sarolangun mengenai Pelaksanaan perlindungan hukum terhadap saksi mahkota dalam perkara pidana, sesuai yang dijelaskan oleh Rikson Lothar:

"Saksi mahkota inikan merupakan pelaku tindak pidana yang dijadikan saksi karena minimnya alat bukti dipersidangan, pelaksanaan perlindungan hukum kepada saksi mahkota sebenarnya saksi mahkota inikan pelaku tindak pidana maka perlakuan yang diberikan kepada ia (pelaku tindak pidana) yang dijadikan saksi ini lebih kepada perlakuan ia sebagai tersangka atau terdakwa, saksi mahkota juga mendapatkan haknya sebagai saksi tetapi lebih kepada hak sebagai pelaku. Seperti hak untuk didampingi penasehat hukum, hak untuk dikunjungi oleh keluarga, hak untuk mendapatkan kesehatan. Dan saksi mahkota ini juga ditahan di lapas seperti halnya tersangka/pelaku tindak pidana pada umumnya, karena saksi mahkota juga merupakan pelaku tindak pidana. Mengenai perlindungan yang diberikan kepada saksi mahkota sama saja seperti halnya saksi tetapi lebih kepada perlindungan ia sebagai pelaku. Dalam persidangannya saksi mahkota ini selalu diperiksa terakhir sekali setelah yang lainnya diperiksa, karena saksi mahkota itu pelaku tindak pidana yang juga dalam perkara itu. Dalam persidangan saksi mahkota juga disumpah seperti saksi-saksi lainnya sebelum memberikan kesaksian."14

Dapat penulis tarik kesimpulan mengenai pelaksanaan perlindungan hukum yang diberikan kepada saksi mahkota dalam perkara pidana. Dalam pernyataan yang diberikan oleh Rikson Lothar saksi mahkota adalah seorang saksi yang juga merupakan pelaku tindak pidana yang berarti tetap harus mempertanggung jawabkan perbuatannya, mengenai pelaksanaan perlindungan hukum terhadap saksi mahkota, perlindungan yang diberikan sama saja seperti saksi pada umumnya atau saksi biasa, tetapi lebih kepada perlindungan ia sebagai pelaku. Saksi mahkota juga ditahan di lapas karena mengingat ia merupakan pelaku tindak pidana. Pernyataan ini tetap ada

13 Wawancara Hakim Pengadilan Negeri Sarolangun, Bpk. Muhammad Affan, 26 November 2019.

14 Wawancara Jaksa Kasubsi Ekonomi, Keuangan Dan Pengamanan Pembangunan Strategis Pada Seksi Intelejen Kejaksaan Negeri Sarolangun, Bpk. Rikson Lothar, 26 November 2019. 
kaitannya dengan Hakim dan Advokat yang telah saya wawancara, tetapi ada perbedaan pada perlakuan yang diberikan kepada saksi mahkota tersebut.

Selain itu penulis juga melakukan wawancara dengan saksi mahkota yang di pilih secara undi di Pengadilan Negeri Sarolangun untuk mengetahui bagaimana pelaksanaan perlindungan hukum terhadap saksi mahkota dalam perkara pidana, sebagaimana dijelaskan oleh Darus Sami Bin A. Kadir (Alm):

"Kalau pelaksanaan perlindungan hukum yang di berikan kepada saya (saksi mahkota) sama saja seperti saksi-saksi pada umumnya, tetapikan saya ini juga merupakan pelakunya, jadi saya di tahan dilapas. Yang saya rasakan pelaksanaannya baik-baik saja, dan saya selaku pelaku sekaligus saksi merasa di perlakukan dengan layaknya manusia tidak ada sedikitpun diskriminasi terhadap diri kami sebagai saksi atau sekaligus pelaku".15

Pernyataan yang sama juga disampaikan saksi mahkota yang lainnya mengenai pelaksanaan perlindungan hukum terhadap saksi mahkota dalam perkara pidana di Pengadilan Negeri Sarolangun, sebagaimana disampaikan oleh Adi Darmawan Bin Syaiul Anwar (Alm):

"Yang saya rasakan terhadap perlindungan yang diberikan kepada diri saya selaku pelaku dan juga dijadikan saksi sangat baik, saya dan kawan-kawan disini diperlakukan dengan baik, perlindungan yang diberikan itu berupa perlindungan fisik, psikis dan hukum, jadi saya selaku pelaku yang dijadikan saksi terhadap perkara saya sendiri merasa aman dalam memberikan kesaksian di pengadilan."16

Dapat penulis simpulkan terhadap dua pernyataan saksi mahkota diatas atas nama Darus Sami Bin A. Kadir (Alm) dan Adi Darmawan Bin Syaiful Anwar (Alm) tentang bagaimana pelaksanaan perlindungan hukum terhadap saksi mahkota dalam proses pemeriksaan perkara pidana di Pengadilan Negeri Sarolangun. Mereka merasa pelaksanaan perlindungan hukum yang diberikan kepada saksi mahkota itu baik-baik saja, perlindungan fisik, psikis dan hukum yang diberikan juga sangat baik, tapi bedanya darus sami dan adi darmawan ini merupakan saksi mahkota jadi harus ditahan demi keaman, dan cenderung perlakuannya lebih kepada ia sebagai pelaku. Perlakuan yang didapat sangat baik dan tidak ada pelecehan terhadap dirinya sebagai pelaku ataupun sebagai saksi.

Saksi dalam suatu kasus perkara pidana khususnya kasus perkara korupsi, narkotika, terorisme, dan pelanggaran Hak Asasi Manusia (HAM) berat sangat rentan dalam keberadaannya, sehingga orang-orang atau para pihak yang berstatus sebagai saksi dan korban tersebut perlu dilindungi dalam bentuk rehabilitasi, pemberian bantuan, dan diberikan motivasi untuk mampu memberikan berbagai keterangan tentang segala hal yang dilihat, didengar, dirasakan, dan atau dialaminya dalam setiap tahapanproses peradilan hukum pidana yang sedang dan akan dihadapinya.

Pemberian perlindungan dalam bentuk rehabilitasi dilakukan dengan cara memberikan terapi medis dan psikososial kepada yang bersangkutan, sedangkan perlindungan dalam wujud bantuan dinyatakan dalam bentuk bantuan upaya

15 Wawancara Saksi Mahkota Dalam Perkara Pidana Di Pengadilan Negeri Sarolangun, Bpk. Darus Sami Bin A. Kadir (Alm), 27 November 2019.

16 Wawancara Saksi Mahkota Dalam Perkara Pidana Di Pengadilan Negeri Sarolangun, Bpk. Adi Darmawan Bin Syaiul Anwar (Alm), 9 April 2020. 
pemenuhan hak-hak proseduralnya, bantuan pendampingan dalam menghadapi proses peradilan hukum atas perkara yang melibatkan dirinya, serta motivasi berupa pengusulan untuk dapat diberikan penggantian kerugian (kompensasi). Bentuk-bentuk perlindungan yang diberikan kepada saksi dapat dikategorikan sebagai berikut:

\section{a. Bentuk perlindungan fisik dan psikis}

Perlindungan atas keamanan diri dalam memberikan kesaksian dimuka persidangan serta bebas dari ancaman dan tekanan pihak lain yang berkaitan dengan kesaksian yang akan, sedang atau telah diberikan. KUHAP yang merupakan ketentuan hukum acara pidana yang bersifat umum tidak secara eksplisit merumuskan hak saksi untuk memperoleh perlindungan atas keamanan pribadi, keluarga, dan harta bendanya, serta dari ancaman yang berkenaan dengan kesaksian yang akan, sedang, atau telah diberikannya. Artinya, dalam perspektif KUHAP, hak saksi seperti diatas tidak perlu dirumuskan didalamnya, cukup apabila ada ancaman atau bahaya yang menimpa saksi atau keluarganya dan sudah memenuhi rumusan delik, maka saksi berarti dilindungi oleh keberadaan delik itu.

Tetapi sebagai dasar hukum bentuk perlindungan diatas terdapat dalam beberapa kebijakan Undang-undang yang lebih khusus, seperti UU Peradilan HAM, UU Perlindungan Saksi dan Korban dan PERPU Tentang Pemberantasan Tindak pidana Terorisme. Undang-undang No. 26 Tahun 2000 tantang Peradilan HAM menjamin hak saksi pelanggaran HAM atas perlindungan fisik dan mentalnya sebagaimana diatur dalam Pasal 34 ayat (1) yang berbunyi: "Setiap korban dan saksi dalam pelanggaran hak asasi manusia yang berat berhak atas perlindungan fisik dan mental dari ancaman, gangguan, teror dan kekerasan dari pihak manapun." Bentuk perlindungan ini juga dijamin dalam PERPU No. 1 Tahun 2002 tantang Pemberantasan Tindak Pidana Terorisme yang diubah menjadi UU No. 15 Tahun 2003 pada Pasal 33 yang berbunyi:

"Saksi, penyidik, penuntut umum, dan hakim yang memeriksa beserta keluarganya dalam perkara tindak pidana terorisme waib diberi perlindungan oleh Negara dari kemungkinan ancaman yang membahyakan diri, jiwa, dan/atau hartanya, baik sebelum, selama, maupun sesudah proses pemeriksaan perkara."

Dalam prakteknya di Pengadilan Negeri Sarolangun perlindungan fisik dan psikis yang diberikan kepada saksi tindak pidana terutama saksi mahkota sudah dilaksanakan dengan baik, semua itu dapat dilihat tidak adanya laporan atau aduan dari setiap orang yang dijadikan saksi pada perkara yang bersangkutan. Pada saat penulis mewawancarai salah satu saksi mahkota pada perkara tindak pidana penggelapan ia merasa dilindungi baik itu berupa perlindungan fisik maupun psikisnya, saksi tersebut mendapatkan hak-haknya sebagai saksi dan memenuhi kewajiban-kewajibannya sebagai saksi. Perlindungan yang diberikan kepadanya sama halnya dengan saksi-saksi pada umumnya, yang membedakan ia ditahan karena juga merupakan pelaku tindak pidana.

\section{b. Bentuk pelindungan hukum}

Saksi tidak dapat dituntut secara hukum baik pidana maupun perdata atas kesaksian yang akan, sedang atau telah diberikannya. Kebijakan sebagaimana diatas sudah dimuat dalam Undang-undang No. 5 tahun 2002 tentang Tindak Pidana 
Pencucian Uang dalam Pasal 43 yang berbunyi: "Pelapor dan/atau saksi tidak dapat dituntut secara hukum baik perdata atau pidana atas pelaporan dan/atau kesaksian oleh yang bersangkutan sabagaimana diamaksud dalam Pasal 40 dan 42".

Ketentuan yang sama juga terdapat dalam Pasal 10 ayat (1) UU PSK yang berbunyi: "Saksi, korban, dan pelapor tidak dapat dituntut secara hukum baik pidana maupun perdata atas laporan, kesaksian yang akan, sedang, atau telah diberikannya".

Akan tetapi ketentuan yang demikian itu tidak berlaku apabila seorang saksi yang juga tersangka dalam kasus yang sama tidak dapat dibebaskan dari tuntutan pidana apabila ia ternyata terbukti secara sah dan meyakinkan bersalah, tetapi kesaksiannya dapat dijadikan pertimbangan hakim dalam meringankan pidana yang akan dijatuhkan. Juga ada pembatasan terhadap tidak dapat dituntutnya saksi, korban atau pelapor atas kesaksiannya yaitu apabila dalam memberikan keterangannya itu tidak dengan itikad baik. Dalam hal ini, maka ia tetap dapat dituntut.

Bentuk perlindungan hukum kepada saksi terutama pada saksi makota di Pengadilan Negeri Sarolangun dinilai sudah diberikan sesuai undang-undang yang mengatur, setiap saksi yang memberikan kesaksian di persidangan dilindungi hakhaknya sebagai saksi berupa tidak dapatnya dituntut kesaksian yang diberikan oleh saksi tersebut, berbeda dengan saksi mahkota, pada prakteknya di pengadilan Negeri Sarolangun Saksi mahkota tetap dapat dituntut tetapi diringankan tuntutannya jika saksi mahkota tersebut beritikad baik.

\section{c. Bentuk perlindungan terkait hak prosedural saksi}

Mendapatkan nasehat hukum untuk bebas memberikan keterangan sesuai dengan kebenaran dan pengetahuannya. Hak mendapat nasehat hukum bagi saksi ini harus dibedakan dengan nasehat yang diberikan kepada tersangka/terdakwa. Terdakwa boleh berbohong atau dengan kata lain tidak ada ancaman pidana jika ia berbohong demi pembelaannya, tetapi saksi tidak boleh berbohong. Nasehat yang diberikan kepadanyan hanya terbatas terhadap hak-haknya, jadi semata-mata dalam usaha keselamatan dirinya untuk bebas memberikan keterangan sesuai dengan kebenaran, sesuai denganpancainderanya, bukan apa yang ada dalam batinnya, bukan yang ia kehendaki akan terjadi. ${ }^{17}$

\section{Kendala Yang Dihadapi Dalam Memberikan Perlindungan Hukum Terhadap Saksi Mahkota di Pengadilan Negeri Sarolangun}

Kendala yang sering kali dihadapi oleh penegak hukum di Pengadilan Negeri Sarolangun dalam penerapan perlindungan hukum terhadap saksi Mahkota dalam perkara pidana salah satunya adalah adanya keengganan dari sebagian besar masyarakat untuk memberikan kesaksian dan keterangan mengenai adanya indikasi telah terjadinya suatu tindak pidana, yang dikarenakan ketakutan mereka akan tidak terjaminnya rasa aman dan ketentraman hidup mereka walaupun sudah ada peraturan perundang- undangan yang tertuang dalam Undang-Undang Nomor 31 Tahun 2014 tentang perubahan atas Undang-Undang Nomor 13 Tahun 2006 tentang Perlindungan Saksi dan Korban yang secara khusus mengatur masalah perlindungan saksi.

17 Muhammad Iksan, Hukum Perlindungan Saksi Dalam Sistem Peradilan Pidana, Cet. 2, Muhammadiyah Univercity Press, Surakarta, 2012, hal 154. 
Selanjutnya dalam Undang-undang tersebut telah ditentukan lembaga khusus yang melaksanakan perlindungan terhadap saksi dan korban yakni Lembaga Perlindungan Saksi dan Korban (LPSK) namun yang menjadi kendala baru yaitu belum adanya pembentukan LPSK di daerah. Saat ini LPSK masih bersifat nasional yang hanya berkedudukan di Ibu Kota Negara yaitu Jakarta. Selain itu keberadaan LPSK dan Undang-Undang No.31 tahun 2014 tentang perubahan Undang-Undang No.13 tahun 2006 tentang Perlindungan Saksi dan Korban masih belum dipahami dan diketahui aparat penegak hukum di daerah.

Dalam hal ada saksi yang diminta oleh terdakwa atau penasihat hukum atau penuntut umum selama berlangsungnya sidang atau sebelum dijatuhkannya putusan, hakim ketua sidang wajib mendengar keterangan saksi tersebut, meskipun ada saksi yang tidak diperiksa di tingkat penyidikan, namun kemudian diajukan pada saat sidang berlangsung atau sebelum putusan, hal tersebut diperbolehkan. Tahap-tahap pemeriksaan sebagai berikut:

\section{a. Pemeriksaan Saksi di Tingkat Penyidikan}

Penyidik karena kewajibannya mempunyai wewenang memanggil orang untuk didengar dan diperiksa sebagai tersangka atau saksi. Di tingkat penyidikan, pemeriksaan saksi harus dibuatkan berita acaranya.Dasar hukum pemeriksaaan saksi di tingkat penyidikan adalah Pasal 112 KUHAP yang berbunyi:

(1) Penyidik yang melakukan pemeriksaan, dengan menyebutkan alasan pemanggilan secara jelas, berwenang memanggil tersangka dan saksi yang dianggap perlu untuk diperiksa dengan surat panggilan yang sah dengan memperhatikan tenggang waktu yang wajar antara diterimanya panggilan dan hari seorang itu diharuskan memenuhi panggilan tersebut.

(2) Orang yang dipanggil wajib datang kepada penyidik dan jika ia tidak datang, penyidik memanggil sekali lagi, dengan perintah kepada petugas untuk membawa kepadanya.

Jika seorang tersangka atau saksi yang dipanggil memberi alasan yang patut dan wajar bahwa ia tidak dapat datang kepada penyidik yang melakukan pemeriksaan, penyidik itu datang ke tempat kediamannya. Saksi diperiksa dengan tidak disumpah kecuali apabila ada cukup alasan untuk diduga bahwa ia tidak akan dapat hadir dalam pemeriksaan di pengadilan. Saksi diperiksa secara tersendiri, tetapi boleh dipertemukan yang satu dengan yang lain dan mereka wajib memberikan keterangan yang sebenarnya. Dalam pemeriksaan tersangka ditanya apakah ia menghendaki didengarnya saksi yang dapat menguntungkan baginya dan bilamana ada maka hal itu dicatat dalam berita acara.

\section{b. Pemeriksaan Saksi di Pengadilan}

Guna menyederhanakan jawaban kami, kami akan menjelaskan tentang pemeriksaan saksi di pengadilan dalam Acara Pemeriksaan Biasa.Hakim dalam menetapkan hari sidang memerintahkan kepada penuntut umum supaya memanggil terdakwa dan saksi untuk datang di sidang pengadilan.Pasal 159 KUHAP berbunyi:

(1) Hakim ketua sidang selanjutnya meneliti apakah semua saksi yang dipanggil telah hadir dan memberi perintah untuk mencegah jangan sampai saksi berhubungan satu dengan yang lain sebelum memberi keterangan di sidang. 
(2) Dalam hal saksi tidak hadir, meskipun telah dipanggil dengan sah dan hakim ketua sidang mempunyai cukup alasan untuk menyangka bahwa saksi itu tidak akan mau hadir, maka hakim ketua sidang dapat memerintahkan supaya saksi tersebut dihadapkan ke persidangan.

Dalam hal ada saksi yang diminta oleh terdakwa atau penasihat hukum atau penuntut umum selama berlangsungnya sidang atau sebelum dijatuhkannya putusan, hakim ketua sidang wajib mendengar keterangan saksi tersebut. Hal ini tercantum dalam Pasal 160 ayat (1) huruf c KUHAP yang berbunyi:

Dalam hal ada saksi baik yang menguntungkan maupun yang memberatkan terdakwa yang tercantum dalam surat pelimpahan perkara dan atau yang diminta oleh terdakwa atau penasihat hukum atau penuntut umum selama berlangsungnya sidang atau sebelum dijatuhkannya putusan, hakim ketua sidang wajib mendengar keterangan saksi tersebut.

Jika ada saksi yang tidak diperiksa di tingkat penyidikan, namun kemudian diajukan pada saat sidang berlangsung atau sebelum putusan, hal tersebut diperbolehkan. ${ }^{18}$ Menanggapi hal tersebut penulis telah melakukan wawancara langung dengan salah satu Hakim di Pengadilan Negeri Sarolangun mengenai kendala yang dihadapi dalam memberikan perlindungan hukum terhadap saksi mahkota, sebagaimana yang dijelaskan oleh Muhammad Affan:

"Selama ini belum ada kendala yang berarti dalam permberian perlindungan hukum terhadap saksi mahkota, karena setiap orang yang dijadikan saksi mahkota disini atas persetujuan pihak yang bersangkutan sebelum pelaku tersebut dijadikan saksi terhadap perkaranya sendiri. Kendala-kendala yang mungkin dapat ditemukan selama di pengadilan yang pertama pelaku atau saksi tersebut menyangkal terhadap apa yang telah mereka perbuat, tetapi selama saya di pengadilan negeri sarolangun ini belum ada yang menyangkal atas perbuatan pidananya, karena pelaku merasa sama-sama melakukan perbuatan pidana itu. Dan selama ini belum ada saksi-saksi yang dapat ancaman dari luar maupun dalam terhadap diri saksi mahkota tersebut, baik dari segi pisik, psikis maupun hal lainnya terhadap saksi mahkota tersebut."19

Dapat penulis simpulkan atas pernyataan yang diberikan salah satu Hakim Pengadilan Negeri Sarolangun terhadap apa saja kendala dalam pemberian perlindungan hukum terhadap saksi mahkota di Pengadilan Negeri Sarolangun yang dijelaskan bahwa tidak ada kendala yang berarti selama ini dalam perlindungan hukum terhadap saksi mahkota di Pengadilan Negeri Sarolangun karena setiap pelaku yang akan dijadikan saksi (saksi mahkota) tersebut atas persetujuan sih pelaku dan tanpa paksaan. Dan tidak ada ancaman sedikitpun terhadap diri saksi mahkota baik dari pisik, psikis ataupun hal lainnya dari luar peradilan maupun dari dalam peradilan.

Selain itu, penulis juga melakukan wawanca dengan salah satu jaksa di Kejaksaan Negeri Sarolangun mengenai apa saja kendala yang ditemukan dalam perlindungan hukum terhadap saksi mahkota dalam perkara pidana, jaksa tersebut atas nama Rikson Lothar selaku Jaksa dibagian Kasubsi Ekonomi, Keuangan Dan

18 https://www.hukumonline.com/klinik/detail/ulasan/lt4ca459db4ecc2/pemeriksaan-saksi-di-tingkatpenyidikan-dan-di-pengadilan/, Diakses tanggal 15 April 2020.

19 Wawancara Hakim Pengadilan Negeri Sarolangun, Bpk. Muhammad Affan, 26 November 2019. 
Pengamanan Pembangunan Strategis Pada Seksi Intelejen Kejaksaan Negeri Sarolangun, sebagaimana dijelaskan sebagai berikut:

"Kalau mengenai kendala yang ditemui dalam upaya pemberian perlindungan hukum kepada saksi mahkota selama ini belum ditemui kendala yang begitu berarti, kendala pasti ada tapi bukan dalam segi perlindungan hukumnya tetapi lebih kepada meyakinkan saksi mahkota tersebut bahwa ia dilindungi keterangannya itu. Karena saksi mahkota itu beda dengan saksi-saksi lain, saksi mahkota ini merupakan saksi yang juga merupakan pelaku maka ia takut jika dijadikan saksi terhadap perkaranya sendiri, tetapi setelah tau ada hukum yang melindungi keterangan yang diberikan oleh saksi barulah biasanya pelaku yakin ingin menjadi saksi terhadap perkaranya sendiri. Kalau mengenai kendala upaya pemberian perlindungan hukum kepada saksi mahkota sendiri selama ini belum ditemukan kendala, karena seperti yang dijelaskan tadi baik saksi maupun pelaku tersebut diberikan perlindungan hukum, maupun pisik dan psikisnya."20

Dari penjelasan yang telah diuraikan narasumber diatas dapat penulis simpulkan mengenai kendala-kendala dalam pemberian perlindungan hukum hukum terhadap saksi mahkota dalam perkara pidana, bahwa hampir selaras semua pernyataan narasumber diatas yang menyebutkan kalau tidak ada kendala-kendala yang begitu penting selama ini, karena perlindungan hukum yang diberikan telah terlaksana dan perlindungan juga diberikan baik dari pisik maupun psikisnya sih saksi mahkota tersebut. Kendala yang ditemui biasanya dalam hal meyakinkan seorang pelaku tindak pidana untuk dijadikan saksi terhadap perkara yang ia juga merupakan pelaku didalamnya. Pelaku ini takut jiwanya terancam jika memberikan kesaksian, dalam hal inilah penegak hukum meyakinkan kalau ia diberikan perlindungan hukum, baik dari segi hukum, pisik maupun psikisnya dan hak-haknya sebagai pelaku juga tetap diberikan ataupun sebaliknya sebagai saksi mahkota. Penulis juga melakukan wawancara dengan saksi mahkota di Pengadilan Negeri Sarolangun mengenai apa saja kendala yang ditemukan dalam perlindungan hukum terhadap saksi mahkota dalam perkara pidana, sebagaimana dijelaskan Abdullah Basit Bin Usman:

“Mengenai kendala yang kami rasakan selaku pelaku yang dijadikan saksi mahkota ini, paling kendala dalam hal takut memberikan kesaksian saat jadi saksi, karena tidak enak hati dengan teman yang lainnya dan juga takut dapat ancaman dari keluarga teman lainnya, tapi alhamdulillah setelah dijelaskan oleh penegak hukum kalau kesaksian yang kami sampaikan itu di lindungi oleh hukum." 21

Selain itu juga ada pernyataan dari salah seorang saksi mahkota lainnya mengenai kendala apa saja yang ditemukan dalam perlindungan hukum terhadap saksi mahkota dalam perkara pidana, yang dijelaskan oleh Saprianto alias Pe'i Bin Muktar:

"Saya selaku saksi yang juga pelaku dalam perkara saya sendiri yaitu perkara narkotika merasa kendala dalam hal keamanan dalam memberikan kesaksian di pengadilan, karena takut diancam dari pihak keluarga atau pun orangnya

20 Wawancara Jaksa Kasubsi Ekonomi, Keuangan Dan Pengamanan Pembangunan Strategis Pada Seksi Intelejen Kejaksaan Negeri Sarolangun, Bpk. Rikson Lothar, 26 November 2019.

21 Wawancara Saksi Mahkota Dalam Perkara Pidana Di Pengadilan Negeri Sarolangun, Bpk. Abdullah Basit Bin Usman, 9 April 2020. 
sendiri yang saya beri kesaksian itu, walaupun saya temannya yang bersamasama berbuat, saya tau kalau kita diberi perlindungan oleh hukum, tapi itu tadi tidak enak hati yang paling jelas."22

Dapat penulis tarik kesimpulan dari dua pernyataan saksi mahkota diatas mengenai apa saja kendala yang ditemukan dalam perlindungan hukum terhadap saksi mahkota dalam perkara pidana, yang mana saksi mahkota ini takut dalam memberikan kesaksian, takut terancam jiwanya jika memberikan kesaksian dalam perkaranya sendiri, baik ancaman dari pihak keluarga pelaku lainnya atau dari hal lain, tetapi baiknya semua keterangan yang diberikan itu dilindungi oleh hukum, baik perlindungan fisik, psikis dan hukumnya. Yang paling utama semua itu berjalan sesuai dengan prosedur-prosedur yang ada dan tidak ada laporan mengenai ancaman kepada saksi terkhusus saksi mahkota.

Walaupun sama-sama mengetahui tentang betapa pentingnya kedudukan dan peran saksi dalam penyelesaian perkara pidana, akan tetapi banyak orang yang secara potensial berkualitas sebagai saksi atau setidaknya sebagai pelapor, atau saksi mahkota itu sendiri tidak bersedia menjadi saksi tidak berani mengungkapkan kesaksian yang sebenarnya. Dalam banyak kasus sering kali saksi enggan mengungkapkan apa yang diketahui maupun dialaminya karena meraka enggan berurusan lebih lanjut dengan aparat penegak hukum. Mereka takut diancam dan diintimidasi atau rasa ketakutan yang dialaminya karena mendapat ancaman dari pelaku kejahatan. Dalam situasi seperti ini, penyidik yang mempunyai kewenangan dalam menemukan dan mengumpulkan bukti, tentu akan mengalami kesulitan dalam menangani perkara yang dimaksud. Dan dalam kondisi inilah penyidik penegak hukum perlu meyakinkan orang tersebut bahwa kesaksian yang ia berikan itu di lindungi oleh hukum dan jiwanya juga dilindungu baik dari segi pisik maupun psikisnya.

Menurut Ibu Nunung Kristiyani selaku Wakil Pengadilan Negeri Sarolangun menyebutkan tentang ketakutan orang menjadi saksi adalah sebagai berikut:

"Ketakutan seorang saksi, sebetulnya bukan saja karena ancaman dan intimidasi pihak tersangka atau terdakwa, juga bukan semata-mata karna rumit dan berbelitnya rentetan proses yang harus mereka lalui, melainkannya juga karena takut terancam menjadi seorang tersangka. Oleh karena itu, dengan alasan membantu pengungkapan kasus, saksi justru berubah statusnya menjadi seorang tersangka. Posisi ini seringkali dialami oleh para saksi dan sekaligus sebagai pelaku tindak pidana, dalam kasus-kasus tertentu. Oleh karena itu, menjamin dan memberikan perindungan bagi saksi secara efektif merupakan hal yang sangat penting. Jika saksi tidak mendapat perlindungan, maka demi keamanan dirinya dan keluarganya, saksi mempunyai kecenderungan untuk mengubah kesaksiannya, bahkan sangat mungkin saksi tidak mau tampil atau maju menjadi saksi. Sehingga menjadi kebutuhan bahwa dalam sidang yang adil memerlukan perlindungan dan dukungan yang baik bagi seorang saksi."23

22 Wawancara Saksi Mahkota Dalam Perkara Pidana Di Pengadilan Negeri Sarolangun, Bpk. Saprianto alias Pe'i Bin Muktar, 9 April 2020.

23 Wawancara Wakil Ketua Pengadilan Negeri Sarolangun, Ibu Nunung Kristiyani, 26 November 2019. 
Di banyak negara, perlindungan saksi dan korban sudah disadari sebagai hal penting dalam proses penegakan hukum. Bahkan, kredibilitas aparat penegak hukum ikut dipertaruhkan karena pentingnya peran saksi dan korban dalam mengungkap suatu peristiwa kejahatan. Saksi yang merasa terancam keselamatannya atau keluarganya, sudah tentu tak akan membeberkan informasi penting yang ia ketahui dalam kesaksiannya. Demikian juga korban. Padahal, kesaksian yang benar dari para saksi sangat penting dalam mengungkap kebenaran suatu tindak kejahatan. Apalagi untuk kejahatan-kejahatan yang dilakukan terorganisir melibatkan kalangan tertentu dengan dampak kejahatan yang besar. Kesadaran akan pentingnya perlindungan terhadap saksi dan korban sudah cukup lama disadari di Indonesia. Pembentukan Lembaga Perlindungan Saksi dan Korban (LPSK) dengan pegangan Undang-Undang Nomor 31 Tahun 2014 tentang perubahan Undang-Undang Nomor 13 Tahun 2006 tentang Perlindungan Saksi dan Korban adalah buktinya.

\section{SIMPULAN}

Berdasarkan apa yang dibahas pada bab sebelumnya, maka dapat ditarik beberapa kesimpulan yang dapat menjawab pokok permasalahan yang diangkat dalam tulisan ini. Pelaksanaan Perlindungan Hukum yang diberikan kepada saksi mahkota di Pengadilan Negeri Sarolangun dinilai telah terlaksana dengan baik, dilihat dari segi perlindungan fisik, psikis maupun hukumnya. Dari hasil wawancara penulis dengan hakim, jaksa dan saksi mahkota itu sendiri pada saat penelitian langsung ke Pengadilan Negeri Sarolangun. Perlindungan fisik, psikis dan hukum yang di dapat saksi mahkota sama halnya yang didapat dengan saksi-saksi pada umumnya atau saksi biasa, hak-hak ia sebagai saksi diberikan sesuai dengan undang-undang dan kewajibannya sebagai saksi juga di penuhi, yang membedakan perlindungan saksi mahkota dengan saksi biasa ialah saksi mahkota di tahan karena juga merupakan pelaku tindak pidana, Tetapi ada juga saksi mahkota yang tidak ditahan karena perkara yang bersangkutan tidak mewajibkan pelakunya ditahan. perlindungan yang diberikan kepada saksi mahkota lebih kepada perlindungan ia sebagai pelaku tindak pidana.

Dalam wawancara penulis kepada Pihak yang bersangkutan di Pengadilan Negeri Sarolangun mengenai kendala-kendala apa saja yang ditemui dalam memberikan perlindungan hukum kepada saksi mahkota dinilai tidak menemui kendala mengenai perlindungan hukum yang diberikan kepada saksi terutama saksi mahkota, semua dilindungi baik fisik, psikis maupun hukumnya. Paling kendala yang ditemui dalam meyakinkan pelaku yang diminta menjadi saksi dalam perkara ia sendiri (penyertaan), pelaku tersebut takut untuk memberikan kesaksian karena takut terancam jiwanya, disinilah tugas penegak hukum untuk meyakinkan bahwa ia dilindungi jiwanya baik itu fisik, psikis maupun hukumnya, hak-hak dan kewajibannya sebagai saksi maupun pelaku juga dipenuhi sesuai dengan undang-undang yang mengatur. 


\section{DAFTAR PUSTAKA}

\section{Dokumen Hukum:}

Republik Indonesia. Undang-Undang Nomor 31 tahun 2014 tentang perubahan Undang-Undang Nomor 13 tahun 2006 tentang Perlindungan Saksi dan Korban.

Republik Indonesia. Undang-Undang Nomor 13 tahun 2003 tentang Pemberantasan Tindak Pidana Terorisme.

Republik Indonesia. Undang-Undang Nomor 5 tahun 2002 tentang Tindak Pidana Pencucian Uang

Mahkamah Konstitusi. Putusan Mahkamah Konstitusi Nomor 42/PUU-VIII/2010 tanggal 3 September 2010.

Mahkamah Konstitusi. Putusan Mahkamah Agung Nomor 2437 K/Pid.Sus/2011 tanggal 7 Februari 2012.

Putusan Mahkama Agung Nomor 250 K/MIL/2013 tanggal 25 maret 2014.

\section{Buku}

Effendi, Erdianto, Hukum Pidana Indonesia; Suatu Pengantar, Cet. 1, PT. Refika Aditama, Bandung, 2011.

Fuady, Munir, Teori Hukum Pembuktian: Pidana dan Perdata, Cet. 4, Pt. Citra Aditya Bakti, 2012.

\& Sylvia Laura L. Fuady, Hak Asasi Tersangka Pidana, Cet. 1, Prenada Media Group, Jakarta,2015.

Hamzah, Andi, Hukum Acara Pidana Indonesia, Edisi Kedua, Cet. 5, Sinar Grafika, Jakarta, 2006.

Harahap, M. Yahya, Pembahasan Permasalahan dan Penerapan KUHAP Penyidikan dan Penuntutan, Cet. 13, Sinar Grafika, Jakarta, 2012.

Pembahasan Permasalahan dan Penerapan KUHAP : Pemeriksaan Sidang Pengadilan, Banding, Kasasi, dan Peninjauan Kembali, Edisi Kedua, Cet. 13, Sinar Grafika, Jakarta, 2012.

Iksan, Muhammad, Hukum Perlindungan Saksi Dalam Sistem Peradilan Pidana, Cet. 2, Muhammadiyah Univercity Press, Surakarta, 2012.

Lamintang, P.A.F dan Theo Lamintang, Pembahasan KUHAP Menurut Ilmu Pengetahuan Hukum Pidana dan Yurisprudensi, Cet. 3, Sinar Grafika, Jakarta, 2013.

Pangaribuan, Luhut M.P., Hukum Acara Pidana \& Hakim Ad Hoc, Cet.1, Papas Sinar Sinanti, Jakarta, 2016.

Prakoso, Djoko, Alat Bukti dan Kekuatan Pembuktian di Dalam Proses Pidana, Cet. 1, Liberty, Yogyakarta, 1988. 
Samosir, C. Djisman, Segenggam tentang Hukum Acara Pidana, Cet. 3 Nuansa Indah, Bandung, 2013.

Sasangka, Hari, Komentar Kitab Undang-undang Hukum Acara Pidana, Cet. 1, CV Mandar Maju, Bandung, 2003.

Jurnal:

Apriliani, Silvia Wulan, Peranan Keterangan Saksi Saksi Sebagai Alat Bukti Dalam Proses Peradilan Pidana (Studi Pada Pengadilan Negeri Ungaran, Skripsi Sarjana Hukum, Universitas Negeri Semarang, 2015, https://lib.unnes.ac.id/21965/.

Cornelis, Fabiandi, Analisis Perlindungan Hukum Bagi Korban Jual Beli Online, Skripsi Sarjana Hukum, Universitas Lampung, Bandar Lampung, 2014, https://jurnal.fh.unila.ac.id/index.php/pidana/article/view/429.

Hadivta, Maria, Tinjauan Yuridis Mengenai Kedudukan Saksi Mahkota Dihadapan Jaksa Penuntut Umum Pada Saat Persidangan, Skripsi Sarjana Hukum, Universitas Lampung, Bandar Lampung, 2013, http://digilib.unila.ac.id/9556/.

Jafar, Asmilawati, Perlindungan Hukum Terhadap Saksi Dalam Pemeriksaan Perkara Pidana, Skripsi Sarjana Hukum, UIN Alauddin Makassar, 2014, http://repositori.uinalauddin.ac.id/6418/1/Asmilawati\%20Jafar.pdf.

Monita, Yulia dan Dheny Wahyudhi, Peranan Dokter Forensik Dalam Pembuktian Perkara Pidana, Jurnal Ilmu Hukum, Fakultas Hukum, Universitas Jambi, Vol. 6, No. 7, 2013, $\quad$ https://onlinejournal.unja.ac.id/index.php/jimih/article/view/2188.

Syamsuningsih, Siti Nurhayati, Perlindungan Hukum Saksi Mahkota Dalam Perkara Tindak Pidana Korupsi, e-Jurnal Katalogis, Vol. 4, Nomor 7, Juli 2016, http://jurnal.untad.ac.id/jurnal/index.php/Katalogis/article/view/6634.

Wahyudhi, Dheny, Perlindungan Terhadap Anak Yang Berhadapan Dengan Hukum Melalui Pendekatan Restorative Justice, Jurnal Ilmu Hukum, Fakultas Hukum, Universitas Jambi, Februari 2015, https://media.neliti.com/media/publications/43318-ID-perlindunganterhadap-anak-yang-berhadapan-dengan-hukum-melalui-pendekatanresto.pdf.

\section{Internet:}

Ali Hitori, Apa Itu Justice Collaborator?, http://.www.kompasiana.com/www.hitori.com/ apa-itu-justice-collaborator_54f60070a33311b9148b4602, diakses tanggal 3 desember 2019.

http://hukumonline.com/klinik/detail/lt50c7ea823e57d/saksi-memberatkan,meringankan,-mahkota-dan-alibi, diakses tanggal 3 desember 2019.

https://www.hukumonline.com/klinik/detail/ulasan/lt4ca459db4ecc2/pemeriksaansaksi-di-tingkat-penyidikan-dan-di-pengadilan/, Diakses tanggal 15 April 2020. 
https://www.kompasiana.com/sitim4ryam/550e2d24813311c42cbc631f/proses-

pemeriksaan-perkara-pidana-di-indonesia?page=all, Diakses tanggal 10 September 2019.

\section{Wawancara :}

Wawancara Hakim Pengadilan Negeri Sarolangun, Bpk. Muhammad Affan, 26 November 2019.

Wawancara Jaksa Kasubsi Ekonomi, Keuangan dan Pengamanan Pembangunan Strategis Pada Seksi Intelejen Kejaksaan Negeri Sarolangun, Bpk. Rikson Lothar, 26 November 2019.

Wawancara Saksi Mahkota Dalam Perkara Pidana di Pengadilan Negeri Sarolangun, Bpk. Darus Sami Bin A. Kadir (Alm), 27 November 2019.

Wawancara Saksi Mahkota Dalam Perkara Pidana di Pengadilan Negeri Sarolangun, Bpk. Adi Darmawan Bin Syaiul Anwar (Alm), 9 April 2020.

Wawancara Saksi Mahkota Dalam Perkara Pidana di Pengadilan Negeri Sarolangun, Bpk. Abdullah Basit Bin Usman, 9 April 2020.

Wawancara Saksi Mahkota Dalam Perkara Pidana di Pengadilan Negeri Sarolangun, Bpk. Saprianto alias Pe'i Bin Muktar, 9 April 2020

Wawancara Wakil Ketua Pengadilan Negeri Sarolangun, Ibu Nunung Kristiyani, 26 November 2019. 